\title{
Isolation, Molecular Characterization and Identification of Antibiotic Producing Actinomycetes from Soil Samples
}

\author{
Fatima Mehaboob Salim ${ }^{1}$, S. Aruna Sharmili ${ }^{1 *}$, J. Anbumalarmathi ${ }^{1}$, K. Umamaheswari ${ }^{2}$ \\ ${ }^{1}$ Department of Biotechnology, Stella Maris College (Autonomous), Chennai, India. \\ ${ }^{2}$ Department of Biotechnology, University of Madras, Guindy Campus, Chennai India.
}

\begin{tabular}{l} 
ARTICLE INFO \\
\hline Article history: \\
Received on: 09/05/2017 \\
Accepted on: 07/07/2017 \\
Available online: $30 / 09 / 2017$ \\
\hline Key words: \\
Antibacterial activity, MIC, \\
DPPH, FT- IR, 16S rRNA, \\
Nocardia alba.
\end{tabular}

\begin{abstract}
A total of 9 actinomycetes (FA1-FA9) isolates were isolated from_soil and water samples using starch casein agar and actinomycetes isolation agar. Except FA4, all the isolates showed antimicrobal activity against one or more of the bacteria (Escherichia coli, Enterococcus faecalis, Klebisella pneumonia and Micrococcus luteus) tested by cross-streak method. The actinomycete isolate FA9 exhibited better antimicrobial efficacy for Gramnegative (E. coli) than Gram-positive organism (E. faecalis) did. Antimicrobial activity of the crude extracts obtained from solid state fermentation showed a better zone of inhibition than those obtained by submerged state fermentation. Minimum inhibitory concentration of the crude extract was $0.51 \mu \mathrm{g} / \mathrm{ml}$ for $E$. Coli and $K$. pneumonia whereas it was $1.02 \mu \mathrm{g} / \mathrm{ml}$ for E. faecalis and M. luteus. The free radical scavenging ability (DPPH) of the ethanolic crude extract recorded $\mathrm{IC}_{50}$ value of 24.384. The FT-IR spectral analyses of extracts showed functional groups such as alcohol $(\mathrm{O}-\mathrm{H})$, alkanes $(\mathrm{C}-\mathrm{H})$, alkene $(\mathrm{C}=\mathrm{C})$ and alkyl halide $(\mathrm{C}-\mathrm{F})$. The isolate FA9 was Gram positive and the spore chain morphology was simple rectus with a smooth spore surface. The $16 \mathrm{~S}$ rRNA gene sequence was closely related to Nocardia alba. The RNA secondary structure predictive of 16SrRNA gene of Nocardia alba showed a free energy of $-152.4 \mathrm{kcal} / \mathrm{mol}$, threshold energy of -4.0 with Cluster factor 2, Conserved factor 2 and Compensated factor 4. The 16SrRNA gene of Nocardia alba showed restriction sites Alu I, Hae III, Bst UI, etc. A GC content of 58\% and AT content of $42 \%$ was obtained based on restriction site analysis.
\end{abstract}

\section{INTRODUCTION}

Actinomycetes are an ubiquitous group of prokaryotes widely distributed in natural ecosystem and a variety of manmade environments (Lam, 2006; Debananda et al., 2009). They are Gram positive branching unicellular bacteria that have unique spore-forming abilities and mycelia structures. The colonies are of pastel colours, soil-like odour, hard and stick to the agar.The term actinomycetes was derived from the Greek words "atkis" (a ray) and "mykes" (fungus) (Das et al., 2008). They have a high guanine $(\mathrm{G})$ and cytosine $(\mathrm{C})$ ratio in their $\mathrm{DNA}(>55 \mathrm{~mol} \%)$ (Goodfellow and Williams, 1983). These soil organisms possess characteristics common to both bacteria and fungi and yet have sufficient distinctive features to delimit them into distinct

\footnotetext{
* Corresponding Author

Aruna Sharmili. S, Department of Biotechnology,

Stella Maris College (Autonomous), Chennai, Tamilnadu, India.

Email: arsharmilis @ gmail.com
}

category (Kumar et al., 2005). Actinomycetes produce aerial hyphae and differentiate into chains of spores (Meera et al., 2013). The aerial mass are of various colours such as white, grey, red, green, blue and violet series, and the various colours of the substrate mycelia vary from grey to greyish yellow to orange, moderate yellow, pale red greyish orange pin, bluish grey and white (Amit et al., 2011).

Melanoid pigments are greenish brown, brownish black or distant black. Reverse-side pigments are pale yellow, olive or yellowish brown. Soluble pigments are recorded as red, orange, green, yellow, blue and violet. Spore surface are observed under electron microscope and are characterized as smooth, spiny, hairy and warty (Sivakumar et al., 2011). The culture conditions for the isolation include enrichment, selective media such as ISP media (1-7), starch casein agar, Kuster agar and asparagine-glucose agar (Baskaran et al., 2011). Various traditional biochemical tests (Aparanji et al., 2013) and molecular methods like 16s rRNA sequencing followed by BLAST can be done to identify them. 
These microorganisms are active in organic matter (carbon and nitrogen) recycling (Thongchai et al., 2003). Many bioactive compounds such asavermectin (Perscot et al., 1993), enzymes such as amylase, lipase, and cellulases produced from actinomycetes play an important role in therapeutic medicines, food, fermentation, textile and paper industries (Mustafa et al., 2004). They are used as plant growth promoters, biocontrol agents, biopesticides and also as a source of agro-active compounds (Mukesh, 2014). The current study was undertaken to isolate, characterize and identify antibiotic producing actinomycetes from soil samples of Chennai, Tamil Nadu.

\section{MATERIALS AND METHODS}

\section{Collection of soil Samples}

Soil samples were collected from Stella Maris College Campus, Adyar River and Marina Beach. All the soil samples were air dried for 10 days to reduce Gram negative bacteria. One gram of Adyar River soil was enriched in $100 \mathrm{ml}$ starch casein broth, $1 \mathrm{gm}$ of Marina Beach soil was added to $100 \mathrm{ml}$ of distilled water and $1 \mathrm{gm}$ of soil collected from Stella Maris College Campus were pre-heated at different temperature $\left(55^{\circ} \mathrm{C}, 65^{\circ} \mathrm{C}\right.$, $75^{\circ} \mathrm{C}, 100^{\circ} \mathrm{C}$ ) for $15 \mathrm{~min}$ to which $100 \mathrm{ml}$ distilled water was added and left in the shaker for 12 hours for the detachment of the spore chains. Serial dilution was done up to $10^{-5}$ and plated on starch casein agar, actinomycetes isolation agar (prepared with $50 \%$ sea water for marine sample) supplemented with streptomycin sulphate $50 \mu \mathrm{g} / \mathrm{ml}$ and nystatin $75 \mu \mathrm{g} / \mathrm{ml}$. The plates were incubated at $28^{\circ} \mathrm{C}$ for 7 to 14 days (Baskaran et al., 2011; Jagan et al., 2013).

\section{Primary Screening}

The antibacterial activity of pure isolates was determined by cross-streak method on nutrient agar (Lemos et al., 1985). The isolated actinomycetes strains were streaked as a parallel line on nutrient agar plates and incubated at $28^{\circ} \mathrm{C}$ for 5 day. After observing a good ribbon like growth, Escherichia coli, Enterococcus faecalis, Klebisella pneumonia and Micrococcus luteus were streaked at right angles to the original streak of actinomycetes and incubated at $28^{\circ} \mathrm{C}$. The inhibition zone was measured after 24-48 hr.

\section{Morphological characterization of the Isolate}

Morphological characters such as colony characteristics, colour of aerial and substrate mycelium and pigment production were studied by inoculating the isolate FA9 in various media such as glycerol yeast extract agar, oatmeal agar, nutrient agar and yeast maltagar and incubated at $30^{\circ} \mathrm{C}$ for $7-15$ days (Baskaran et al., 2011). Spore surface features were studied under scanning electron microscope (SEM).Gram staining was carried according to the method of Bailey and Scott, 1966.

\section{Cover Slip Culture Method}

The arrangement of spore and sporulating structures was examined microscopically using cover slip culture method
(Gebreselema et al., 2013). A sterile cover-slip was inserted at an angel of $45^{\circ} \mathrm{C}$ in the centre of a nutrient agar plate. A loop full of the culture taken from a seven day old culture plate was inoculated at the insertion place. After 7 days of incubation at $30^{\circ} \mathrm{C}$, the cover slip was removed and placed upwards on a clean glass slide. The culture was fixed with few drops of methanol for $15 \mathrm{~min}$ and washed with running tap water and flooded with crystal violet for 1 min followed by washing and drying. The cover-slip was finally examined under the microscope (100X).

\section{Biochemical Tests}

Biochemical tests such as indole production, methyl red(MR), Voges Proskauer (VP), citrate utilization, starch hydrolysis, gelatin liquefaction, casein hydrolysis, urease production, oxidase test, catalase test and coagulation of milk were carried according to International Streptomyces Project(ISP) (Shirling and Gottlieb, 1996).The results were compared with Bergey's Manual of Determinative Bacteriology.

\section{Assimilation of Carbon Sources}

The ability of the isolate FA9 in utilizing various carbon compounds as source of energy was studied by following the method recommended in ISP using carbon utilization medium. Growth was observed by comparing them with positive and negative control.

\section{Secondary Screening for Antimicrobial Activity}

The mature spores of the isolate were inoculated in 100 $\mathrm{ml}$ of ISP 2 broth and incubated at $30^{\circ} \mathrm{C}$ in rotary shaker at $200 \mathrm{rpm}$ for 15 days. The fermented broth was centrifuged at $5000 \mathrm{rpm}$ at $4^{\circ} \mathrm{C}$ for $20 \mathrm{~min}$. The supernatant was collected and the antibacterial activities of E. coli, E. faecalis, K. Pneumonia and M. luteus were tested. The test bacterial isolates were cultured in nutrient broth at $37^{\circ} \mathrm{C}$ for $18 \mathrm{hr}$ and the turbidity was adjusted to $10^{-5}$ cells using Mac Farland standard and $100 \mu$ l of the same was plated on to the plate. Wells were cut using sterile cork borer and various volumes $(50 \mu 1,75 \mu 1$ and $100 \mu 1)$ of extract were added. Streptomycin sulphate $(1 \mu \mathrm{g} / 100 \mu \mathrm{l})$ was taken as the positive control. The plates were incubated at $37^{\circ} \mathrm{C}$ for $24 \mathrm{hr}$ (Baskaran et al., 2011).

\section{Production of Secondary Metabolite from Crude Extract}

\section{Submerged State Fermentation}

One hundred millilitre of the ISP2 broth was dispensed into $250 \mathrm{ml}$ conical flask, sterilized, cooled and inoculated with 2 $\mathrm{ml}$ suspension of pure FA9 isolate and left in the rotary shaker at 200rpm (Gebreselema et al., 2013) for 15 days. The fermented broth was centrifuged at $5000 \mathrm{rpm}$ at $4^{\circ} \mathrm{C}$ for $20 \mathrm{~min}$. The supernatant was collected and equal volume of ethyl acetate was added and shaken vigorously at regular intervals. The solvent phase was separated from aqueous phase using separating funnel and evaporated at room temperature to remove the solvent. The crude extracts obtained were stored for further use. 


\section{Solid State Fermentation}

To one hundred gram of the substrate (red rice grains) $100 \mathrm{ml}$ of distilled water was added and boiled until the rice grains softened. Mineral salt solution was added to the flask and autoclaved at $121^{\circ} \mathrm{C}$ for 15 minutes (Gebreselema et al., 2013). It was cooled and inoculated with $2 \mathrm{ml}$ of the culture suspension from15-day-old FA9 isolate grown on oat meal agar and the flasks were incubated at $30^{\circ} \mathrm{Cwas} 15$ days. The completely fermented rice grains were ground in mortar and pestle and allowed to dry for 24 hours at room temperature. One hundred millilitre of ethyl acetate and $100 \mathrm{ml}$ of methanol were added to the extract and placed on rotary shaker at $120 \mathrm{rpm}$ for 12 hours. The extract was filtered through Whatman filter paper and the solvent phase was removed by evaporation at room temperature. The crude extract was stored for further studies.

\section{Antimicrobial Analysis of the Crude Extract}

The crude extract obtained was weighed and resuspended in $1 \mathrm{ml}$ methanol and a stock solution of known concentration was prepared and used for antimicrobial analysis (Polpass and Solomon, 2013). Antibacterial activities of the crude extract obtained from submerged state and solid state fermentation were tested using agar well diffusion method. Bacterial cultures ( $E$. coli, E. faecalis, K. pneumonia, M. luteus) were cultured in nutrient broth at $37^{\circ} \mathrm{Cfor} 18 \mathrm{hr}$. The turbidity of the test bacterial cultures were adjusted to $10^{-5}$ cells using MacFarland standard and $100 \mu \mathrm{l}$ was plated on to the plate. Wells were cut using sterile cork borer and different volumes $(50 \mu 1,75 \mu 1,100 \mu 1)$ of crude extracts were added. Streptomycin sulphate $(1 \mu \mathrm{g} / 100 \mu \mathrm{l})$ was taken as the positive control and sterile distilled water as negative control.

\section{Determination of Minimum Inhibitory Concentration (MIC)}

E. coli, E. faecalis, K. pneumonia, M. luteus were used for determination of MIC. One millilitre of nutrient broth was dispensed into 10 test tubes and $2 \mathrm{ml}$ into $11^{\text {th }}$ test tube (broth control). Two millilitre of the crude extract alone was added in the $12^{\text {th }}$ test tube (crude extract broth). One millilitre of crude extract solution was added to test tube 1 and 2 and serial dilution was done from the $2^{\text {nd }}$ up to the $10^{\text {th }}$ test tube. Finally, $1 \mathrm{ml}$ was discarded from the $10^{\text {th }}$ test tube. One hundred millilitre of inoculum was added into test tubes 1 to 10 and incubated at $37^{\circ} \mathrm{C}$ for 18-24 hours. After overnight incubation, the lowest concentration inhibiting the visible growth of the microorganism was considered as the MIC value (Gebreselema et al., 2013).

\section{Estimation of Radical Scavenging Activity (RSA) by DPPH Assay}

The crude extracts of solid state fermentation of actinomycete isolate FA9 were taken at various concentrations (20-80 $\mu \mathrm{g} / \mathrm{ml})$ and make up to $1 \mathrm{ml}$ using methanol. One millilitre of $0.1 \mathrm{mM}$ DPPH was added to all the test concentrations and kept in the dark at room temperature for $30 \mathrm{~min}$. The absorbance of the solution was read at $517 \mathrm{~nm}$ in UV spectrophotometer. The percentage inhibition and $\mathrm{IC}_{50}$ values were calculated with ascorbic acid as the reference and DPPH as the control. The concentration of dry weight material per millilitre of solvent $(\mu \mathrm{g} / \mathrm{ml})$ that inhibits the formation of DPPH radicals by $50 \%$ is defined as $\mathrm{IC}_{50}$ value (Sandhya et al., 2016).

$\%$ of DPPH radical scavenging activity $=$

$$
\frac{\mathrm{Abs}_{\text {control}}-\mathrm{Abs}_{\text {sample }} \times 100}{\mathrm{Abs}_{\text {control }}}
$$

$\mathrm{Abs}_{\text {control }}$ is the absorbance of DPPH radical+ethanol

$\mathrm{Abs}_{\text {sample }}$ is the absorbance of DPPH radical + crude extract

The procedures were performed in triplicate. $\mathrm{IC}_{50}$ (concentration providing 50\% inhibition) value was calculated graphically using a calibration curve versus percentage of inhibition.

\section{Characterization of Crude Extract by Infrared Spectroscopy (FT-IR)}

The infrared (IR) spectra of the crude ethyl acetate extract of the actinomycete isolate FA9 was measured (as $\mathrm{KBr}$ discs)) between 400 and4000 $\mathrm{cm}^{-1}$ on Perkin Elmer 2000 FT-IR spectrophotometer (Arulappan et al., 2012). The functional groups and types of vibrations were assessed based on the peak values.

\section{DNA Isolation and Amplification}

The actinomycete FA9 was grown in ISP2 broth for 3 days and the total genomic DNA was extracted according to the procedure of Sambrook et al. (2011). The16SrRNA gene fragment was amplified using Universal Primers (Actino Specific Forward Primer -5'-CGTATTACACATGCAAGTCGA-3' and Actino Specific Reverse primer- 5'CGTATTACCGCGGCTGCTGG-3') (Nilson and Strom, 2002). PCR amplifications were carried out in a final volume of $20 \mu \mathrm{l}$ of reaction mixture containing $10 \mu$ lof master mix, $1 \mu \mathrm{l}$ of each primer $(20 \mathrm{pmol} / \mu \mathrm{l}), 1 \mu \mathrm{l}$ (approximately $200 \mathrm{ng}$ ) of template DNA and $7 \mu \mathrm{l}$ of sterile Millipore water. Amplification was for 30 cycles $\left(94^{\circ} \mathrm{C}\right.$ for $5 \mathrm{~min}, 94^{\circ} \mathrm{C}$ for $40 \mathrm{sec}$, $52^{\circ} \mathrm{C}$ for $1 \mathrm{~min}$ and $72^{\circ} \mathrm{C}$ for $90 \mathrm{sec}$ and final extension at $72^{\circ} \mathrm{C}$ for $10 \mathrm{~min}$ ). $2 \mu \mathrm{l}$ of the PCR-amplified products was confirmed on $2 \%$ agarose gel and the molecular size of the amplified product was determined using a standard 1-kb DNA ladder.

\section{Purification of PCR Products and Sequencing}

Amplified DNA products were purified by PCR clean-up kit (Bangalore Genei) before sequencing. Automated sequencing was carried out according to the dideoxy chain termination method (Sanger and Coulson, 1975).

\section{Sequencing Similarities and Phylogenetic Analysis}

The complete DNA sequence of the 16SrRNA was analysed and compared using the Entrez search engine (http://www.ncbi.nlm.nih.gov/nuccore/).The BLAST program (www.ncbi.nlm.nih.gov/blst) was employed in order to assess the degree of DNA similarity. Multiple sequence alignment and molecular phylogeny were evaluated using MEGA6. The 
phylogenetic tree was displayed using the TREEVIEW program. The 16S rRNA sequences were submitted to the GenBank, NCBI, USA.

\section{Secondary Structure Prediction and Restriction Site}

The RNA secondary structure of the isolate FA9 was predicted using Gene BEE online software (http://www.genebee.msu.su/services/rna2_reduced.html) by Greedy method and the restriction sites of the DNA of the strain were analysed by NEB cutter online tool version 2.0 (http://tools.neb.com/NEBcutter2/).

\section{RESULTS AND DISCUSSION}

\section{Actinomycetes Isolation and Primary Screening}

A total of $\mathrm{f}$ nine actinomycetes were isolated from the sampling sites. Primary screening results indicated that all the isolates FA1-FA9 showed antibacterial activity against at least one of the bacteria tested, except FA4 which had no activity. Bacterial isolate FA9 exhibited broad-spectrum activity against E. coli, E. faecalis, K. Pneumonia and M. luteus and hence chosen for further studies. Aparanji et al. (2013) also reported that all the 42 actinomycete strains tested had antibacterial activity similar to the present study. The actinomycete isolate FA9 had white colonies on all types of agar used. Ariel mass was white while the substrate mycelium was yellow and no pigments were produced (Figure 1). It stained Gram positive and the spore chain morphology was simple rectus. The spore surface was smooth as identified by SEM (Figure 2).A similar report of branched, filamentous and microspore chain colonies with smooth spore surface morphology has been reported by Imran et al. (2012).

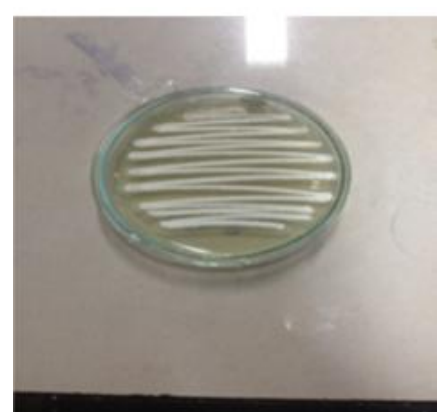

Fig. 1: Morphology of Nocardia alba (FA9).

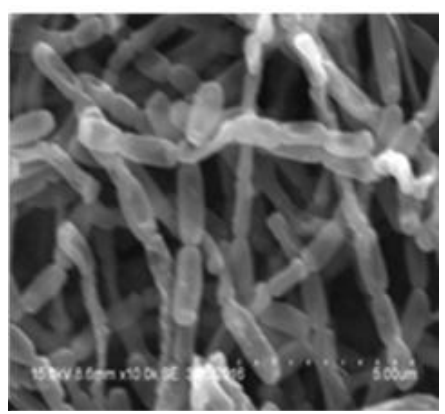

Fig. 2: SEM analysis of Spore Surface Morphology of Nocardia alba (FA9).

\section{Biochemical Characterization and Assimilation of Carbon Sources}

The actinomycete isolate FA9 showed positive for MRVP, citrate utilization, starch hydrolysis, gelatin liquefaction, casein hydrolysis, urease, oxidase, catalase, coagulation of milk, and negative for indole. Excellent growth was observed in basal media with $1 \%$ of maltose (strongly positive $(++)$ ) followed by fructose plates(doubtful $( \pm)$ ) whereas sucrose and xylose was not utilized (Table 1).
Table 1: Biochemical Characteristics of Nocardia alba (FA9).

\begin{tabular}{lc}
\hline Characteristic & Result \\
\hline Spore chain & Rectus \\
Indole & - \\
Methyl Red -VogesProskauer & + \\
Citrate utilization & + \\
Starch hydrolysis & + \\
GelatinLiquefaction & + \\
Casein hydrolysis & - \\
Urease production & + \\
Oxidase & + \\
Catalase & + \\
Coagulation of milk & Carbon utilization \\
\hline Maltose & ++ \\
Fructose & \pm \\
Xylose & - \\
Sucrose & - \\
\hline
\end{tabular}

(+ Positive; - Negative; \pm Doubtful).

\section{Antimicrobial Activities}

Secondary screening of FA9 showed antibacterial activity against E. coli $(11 \mathrm{~mm})$, E. Faecalis $(6 \mathrm{~mm}), K$. pneumonia (1mm), Micrococcus luteus (2mm). In the present study, Gramnegative bacteria were highly susceptible to the crude extracts compared to Gram-positive bacteria, which is in contrast to the reports of Stephen (2014) and Gebreselema et al. (2013). FA9 had a zone of $8 \mathrm{~mm}$ against $E$. coli, $5 \mathrm{~mm}$ against E. faecalis, $2 \mathrm{~mm}$ against $K$. pneumonia and $3 \mathrm{~mm}$ against Micrococcus luteus at a concentration of $500 \mu \mathrm{g} / \mathrm{ml}$ of crude extracts obtained from submerged state fermentation (Figure 3a).

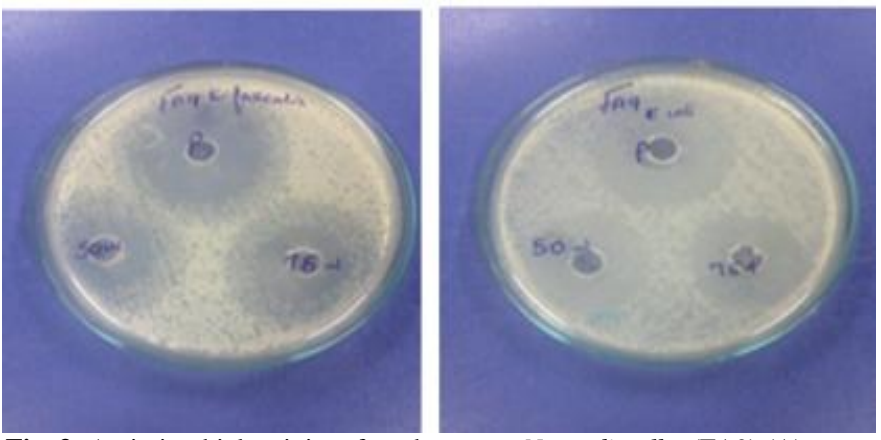

Fig. 3: Antimicrobial activity of crude extract Nocardia alba (FA9) (A) submerged state fermentation (B) solid state fermentation.

Tara et al. (2009) reported similar antibacterial activity against E.coli ATCC-49132, Proteus mirabilsATCC-49132, P. vulgaris, K. pneumonia, K. oxytoca, Staphylococcus aureus ATCC29213, Bacillus subtilis, Shigella species, Salmonella typhi and Salmonella paratyphi A. FA9 had a zone of $9 \mathrm{~mm}$ against E. coli, $6 \mathrm{~mm}$ against $E$. faecalis, $2 \mathrm{~mm}$ against $K$. pneumonia and $3 \mathrm{~mm}$ against Micrococcus luteus at a concentration of $500 \mu \mathrm{g} / \mathrm{ml}$ of crude extract obtained from solid state fermentation (Figure $3 b$ ). In the current investigation, the antibacterial activity of the crude extract produced in solid state fermentation was high in comparison to the submerged state fermentation (Figure 4). 


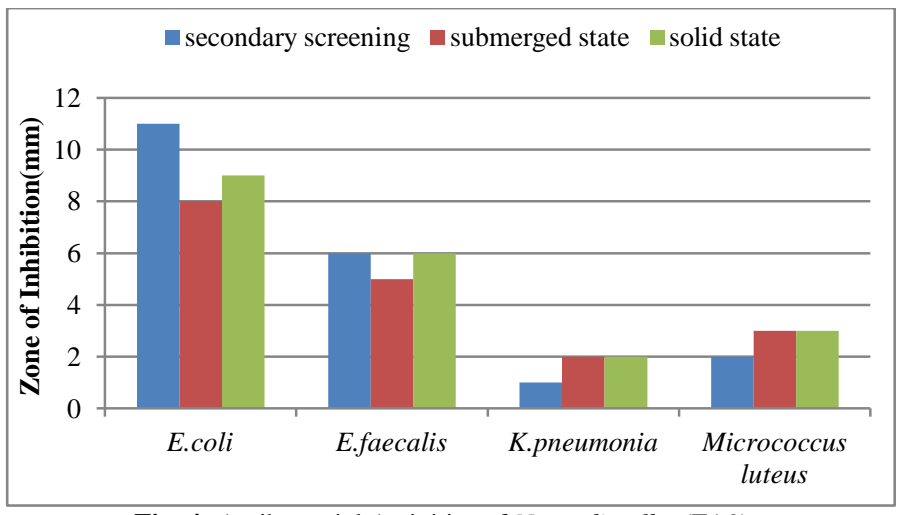

Fig. 4: Antibacterial Activities of Nocardia alba (FA9).

\section{Minimum Inhibitory Concentration (MIC)}

MIC of the crude extract FA9was $0.51 \mu \mathrm{g} / \mu \mathrm{l}$ against $E$. coli and K. pneumonia, $1.02 \mu \mathrm{g} / \mu \mathrm{l}$ against E. Faecalis and $M$. luteus. Tara et al. (2009) reported that isolate K.6.3 had an MIC of $1 \mathrm{mg} / \mathrm{ml}$ and isolates K.14.2 and K.58.5 had an MIC of $2 \mathrm{mg} / \mathrm{ml}$ against S. aureus ATCC 29213.Hotam et al. (2013) recorded an MIC of $2.5 \mathrm{mg} / \mathrm{ml}$ against $E$. coli by the isolates AS23, AS33 and AS34.

\section{Estimation of Radical Scavenging Activity (RAS) by DPPH Assay}

The percentage inhibitory effect of crude extract (1000 $\mu \mathrm{g} / \mu \mathrm{l})$ against DPPH was calculated. In the crude extract of FA9, the percentage of inhibition was $24 \%$, with the $\mathrm{IC}_{50}$ value of $24.384 \pm 12.95$ (Figure 5). In a similar work, Arulappan et al. (2012) reported a dose dependent scavenging activity of the ethyl acetate extract.

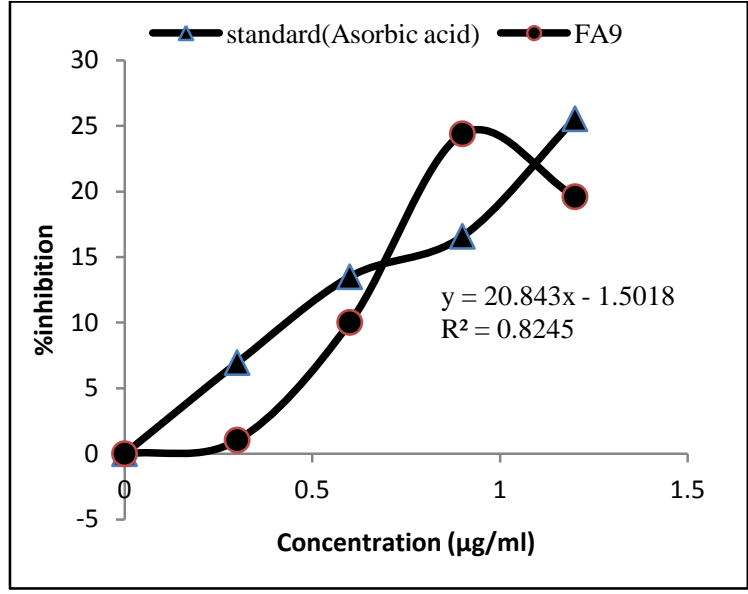

Fig. 5: FT-IR of Crude Extract of Submerged State Fermentation of Nocardia alba (FA9).

\section{Characterization of Crude Extracts by Infrared spectroscopy}

The FT-IR spectrum of antimicrobial substance produced

by FA9 showed peaks at $3359.18 \mathrm{~cm}^{-1}, 2927.10 \mathrm{~cm}^{-1}, 1647.2$ $\mathrm{cm}^{-1}$ and $1033.89 \mathrm{~cm}^{-1}$,corresponding to the following functional groups such as alcohol $(\mathrm{O}-\mathrm{H})$, alkanes $(\mathrm{C}-\mathrm{H})$, alkene $(\mathrm{C}=\mathrm{C})$, alkyl halide $(\mathrm{C}-\mathrm{F})$, respectively (Figure 6, Table 2). Similarly, Iman (2014) reported absorbance ranging from 3529 to $3468 \mathrm{~cm}^{-1}$ for the isolate streptomyces KGL-13, corresponding to amine group. Arulappan et al. (2012) also reported a peak of3398 $\mathrm{cm}^{-1}$ that is characteristic of hydroxyl $(\mathrm{O}-\mathrm{H})$ and 3 common vibrational peaks between 2899 and $2977 \mathrm{~cm}^{-1}$ that are characteristic of a $v(\mathrm{C}-\mathrm{H})$ symmetrical vibration of saturated hydrocarbon in their study.

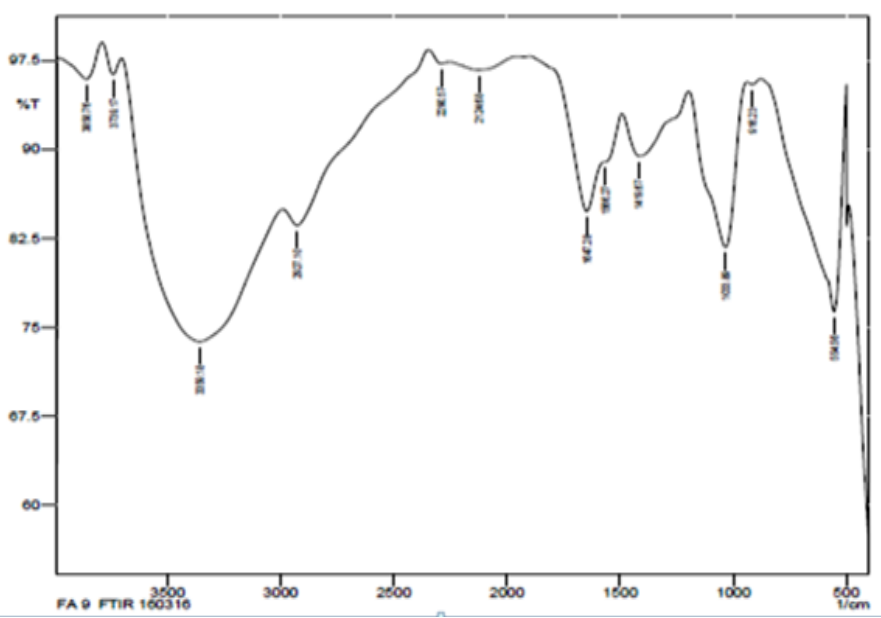

Fig. 6: FT-IR of Crude Extract of submerged state.

Table 2: FT-IR analysis of crude extract of submerged state fermentation of Nocardia alba (FA9).

\begin{tabular}{rlll}
\hline $\begin{array}{r}\text { Peak } \\
\text { Value } \\
\left(\mathbf{C m}^{-\mathbf{1}}\right)\end{array}$ & Intensity & Functional Group & Types Of Vibration \\
\hline 3359.18 & Strong Broad & O-H (Alcohol) & Stretching,H-Bonded \\
2927.10 & Strong & C-H (Alkane) & Stretching \\
1647.28 & Variable & C=C (Alkene) & Stretching \\
1033.89 & Strong & C-F(Alkyl Halide) & Stretching \\
\hline
\end{tabular}

\section{Analysis of PCR Products and Sequencing}

The 16S rRNA gene sequence from the strain FA9 was closely related to Nocardia alba and was retrieved from GeneBank database using BLAST. The sequence was submitted in the GeneBank and accession number MF063067 was obtained. Phylogenetic tree constructed using Clustal Omega based on $16 \mathrm{~S}$ rRNA gene sequence in comparison to FA9 showed it was related members of the genus Nocardia (Figure 7).

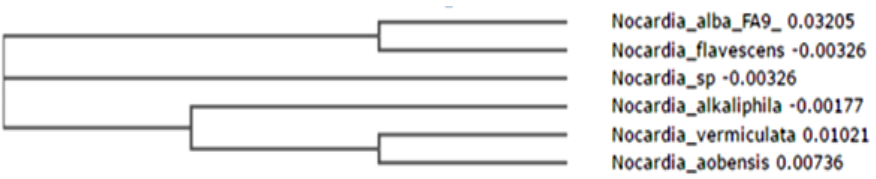

Fig. 7: Phylogenetic tree based on 16S rRNA gene sequence comparison of FA9 (Nocardia alba).

\section{Prediction of Secondary Structure and Restriction Sites Analysis}

The RNA secondary structure predictive of $16 \mathrm{~S}$ rRNA gene of Nocardia alba showed a free energy of $-152.4 \mathrm{kcal} / \mathrm{mol}$, threshold energy of -4.0 with Cluster factor 2, Conserved factor 2 and Compensated factor 4 (Figure 8). The 16SrRNA gene of Nocardia alba showed restriction sites for Alu I, Hae III, Bst UI, etc. and had a GC content of $58 \%$ and AT content of $42 \%$ (Figure 9). 


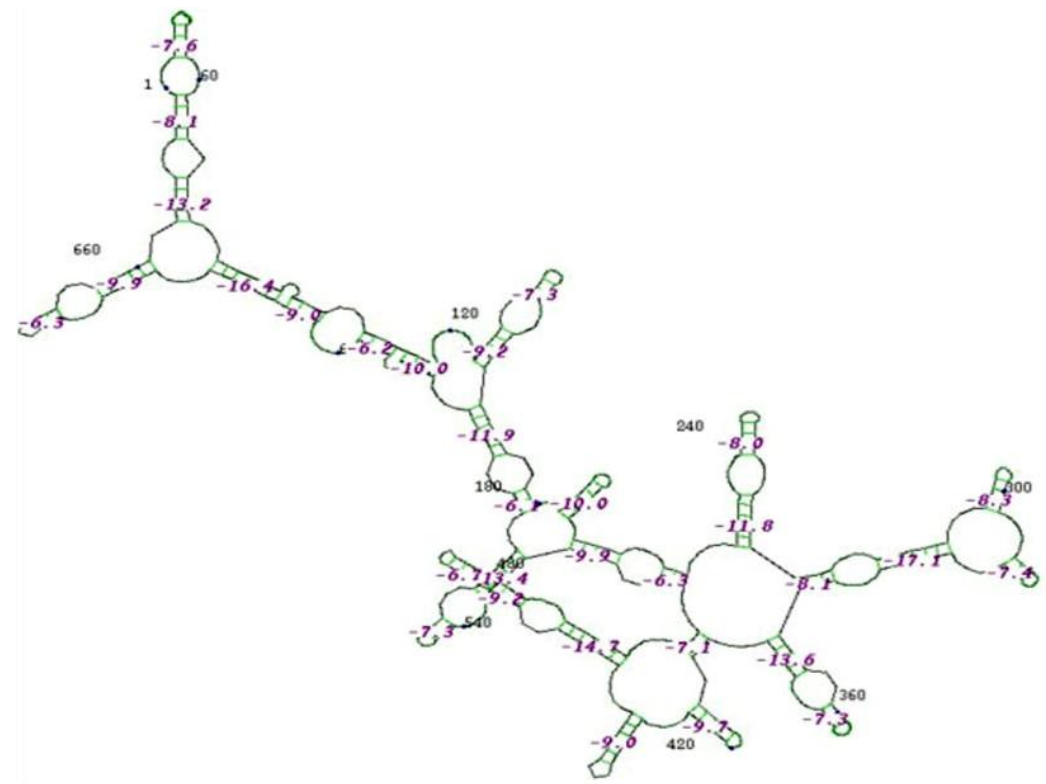

Fig. 8: RNA Secondary structure of Nocardia alba (FA9).

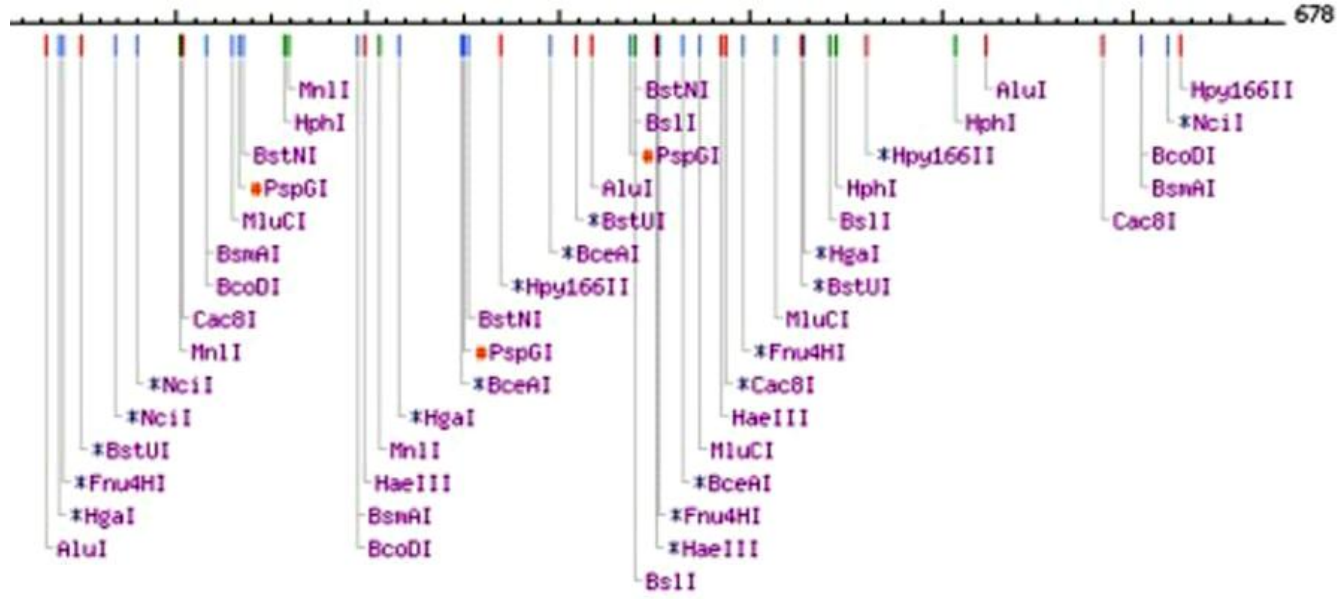

Fig. 9: Restriction sites prediction of Nocardia alba (FA9).

\section{CONCLUSION}

In the present study, Gram negative organism (E. coli) was efficiently inhibited compared to the Gram-positive $E$. faecalis, as seen from the results of secondary screening and the activity of the crude extracts from solid and submerged state fermentation. Antimicrobial activity of the crude extracts obtained from solid state fermentation showed a better zone of inhibition from those obtained by submerged state fermentation. The MIC value of the Gram-negative E.coli was $0.51 \mu \mathrm{g} / \mathrm{ml}$ when compared to Gram-positive E. faecalis $(1.02 \mu \mathrm{g} / \mathrm{ml})$. Results of the present investigation indicate that the actinomycete isolate FA9 can be used for the isolation of bioactive compound that can be used as a drug.

\section{ACKNOWLEDGEMENT}

Authors thank the principal and the management of Stella Maris College (Autonomous), Chennai, Tamil Nadu, India, for the research facilities provided.
Financial support and sponsorship: Nil.

Conflict of interest: The authors declare no conflict of interest.

\section{REFERENCES}

Amit P, Imran A, Kailash SB, Tanushri C, Vidyottma S. Isolation and characterization of Actinomycetes from soil and evaluation of antibacterial activities of actinomycetes against pathogens. Int J Appl Biol Pharm, 2011; 2(4):384-392.

Aparanji P, Venkata RL, Murali K. Isolation of potent antibiotic producing actinomycetes from marine sediments of Andaman and Nicobar Marine Islands. J Microbio Antimicrobio, 2013; 5(1):6-12.

Arulappan JP, Sagadevan E, Dhanalakshmi P, Sathish KS, Karthikeyan V, Arumugam P. Detection of antioxidant and antimicrobial activities in marine actinomycetes isolated from Puducherry Coastal Region. J Mod Biotech, 2012; 1(2): 63-69.

Bailey and Scotts. 1966. Diagnostic Microbiology. $2^{\text {nd }}$ ed. Saint Louis: C V Mosby.

Baskaran R, Vijayakumar R, Mohan PM. Enrichment method for the isolation of bioactive actinomycetes from mangrove sediments of Andaman Islands. Malays J Microbio, 2011; 7(1): 26-32. 
Das S, Lyla PS, Khan SA. Characterization and identification of marine actinomycetes existing systems, complexities and future directions. Natl Acad Sci Lett, 2008; 31(5):149-160.

Debananda SN, Suchitra, Sanasam, Salam N. Screening of actinomycete isolates from niche habitats in Manipur for antibiotic activity. Am J Biochem Biotech, 2009; 5(4):221-225.

Gebreselema G, Feleke M, Samuel S, Nagappan R. Isolation and characterization of potential antibiotic producing actinomycetes from water and sediments of Lake Tana, Ethiopia. Asian Pac J Biomed, 2013; 3(6):426-435.

Goodfellow M, Williams ST. Ecology of actinomycetes. Annu Rev Microbio. 1983; 37:189-216.

Hotam SC, Jayprakash Y, Anju RS, Smriti S, Anil KS, Natrajan G. Antibacterial activity of actinomycetes isolated from different soil samples of Sheopur. J Adv Pharm Technol Res, 2013; 4(2): 118-123.

Iman MJ. Screening for antimicrobial agents producing actinomycetes isolated from agricultural soils in Hilla/Iraq. IOSR J Pharm BiolSci, 2014; 9(2): 47-52.

Imran U, Masood A, Muhammad JI, Uzma N, Waqar AJ, Muhammad AJ. Actinomycetes screening for bioactive potential isolated from the moist forest soils of Pakistan. Rec Zool Surv, 2012; 21:10-13.

Jagan MYSYV, Sirisha B, Haritha R, Ramana. Selective screening, isolation and characterization of antimicrobial agents from marine actinomycetes. Int J Pharm PharmSci, 2013; 5(4):443-449.

Kumar SV, Sahu MK, Kathiresan K. Isolation and characterization of Streptomycetes producing antibiotics from a mangrove environment. Asian J Microbio Biotech Environ Sci,2005; 7(3):457-464.

Lam, Kin S. Discovery of novel metabolites from marine actinomycetes. CurrOpionMicrobiol, 2006; 9(3):245-251.

Lemos ML, Toranzo AE and Barja JL. Antibiotic activity of epiphytic bacteria isolated from intertidal seaweeds. J Microbial Ecol, 1985;11: 149-163.

Meera K, Bat EM, Birenda P, Madhusudan C. Identification and characterization of antibiotic-producing actinomycetes isolates. Am J Microbio, 2013; 4(1):24-31.

Mukesh S. Actinomyetes: Source, identification, and their applications. Int J Curr Microbio Appl Sci, 2014; 3(2):801-832.

Mustafa OA, Usame T, Cem A. Antibacterial activity of some actinomycetes isolated from farming soils of Turkey. Afr J Biotech, 2004; 3(9):441-446.

Nilson WB, Strom MS. Detection and identification of bacterial pathogens of fish in kidney tissue using terminal restriction fragment length polymorphism analysis of $16 \mathrm{~S}$ r RNA genes. Dis Aquat Org, 2002; 48: $175-185$.
Polpass AJ and Solomon RDJ. Phylogenetic appraisal of antagonistic, slow growing actinomycetes isolated from hypersaline inlands solar salterns at Sambhar salt Lake, India. Front Microbio, 2013; $4: 1-9$.

Sambrook J, Fritsh EF, Maniatis T. 2011. Molecular Cloning a Laboratory Manual; Cold Spring Harbour Laboratory Press: New York, USA.

Sandhya S, Aruna SS, Anbumalarmathi J, Umamaheswari K. Phytochemical analysis, GC-MS composition, antibacterial, antioxidant activity of Nyctanthes arbortristis and Nerium oleander. J Chem Bio PhySci, 2016; 6(2): 415-426.

Sanger F and Coulson AR. A rapid method for determining sequences in DNA by primed synthesis with DNA polymerase. J MolBiol, 1975; 94(3): 441-448.

Shirling EB and Gottlieb D. Methods for characterization of Streptomyces species. Int J SystBacteriol, 1966; 16: 313- 340.

Sivakumar K, Haritha R, Jagan MYSYV, Ramana T. Screening of marine actinobacteria for antimicrobial compounds. Res $\mathrm{J}$ Microbio, 2011; 6(4):385- 393.

Stephen K A. Isolation of actinomycetes from Soil. J Microbiol Res, 2014; 4(3): 136-140.

Tara DG, Chringma S, Vishwanath PA, Binod L. Isolation and characterization of antibacterial actinomycetes from soil samples of Kalapatthar, Mount Everest Region.Nep J Sci Tech, 2009; 10:173-182.

Thongchai T, John F P, Saisamorn L. Isolation of endophyticactinomycetes from selected plants and their antifungal activity. World J Microbio Biotech, 2003; 19(4):381-38

\section{How to cite this article:}

Salim FM, Sharmili SA, Anbumalarmathi. J, Umamaheswari K. Isolation, Molecular Characterization and Identification of Antibiotic Producing Actinomycetes from Soil Samples. J App Pharm Sci, 2017; 7 (09): 069-075. 